\title{
Topotecan Weekly Regimen
}

National Cancer Institute

\section{Source}

National Cancer Institute. Topotecan Weekly Regimen. NCI Thesaurus. Code C160132.

A chemotherapy regimen consisting of weekly topotecan that may be used in the treatment of cervical, ovarian, fallopian tube, and primary peritoneal cancers. 